\title{
Analysis Study of Factors Affecting Students 'Digital Literacy Competency
}

\author{
Ratna Sari Dewi , Universitas Islam Negeri Syarif Hidayatullah Jakarta, Indonesia, ratna@uinjkt.ac.id \\ Fahrurrozi , Universitas Negeri Jakarta, Indonesia \\ Uswatun Hasanah, Universitas Negeri Jakarta, Indonesia \\ Muhammad Zuhri Dj, Institut Agama Islam Negeri Bone, Sulawesi Selatan
}

\begin{abstract}
This study aims to describe the factors that influence digital literacy competence and the dominant factors that influence it. The method used in this research is descriptive method with a quantitative approach. The research sample of students of the primary school teacher education study program Universitas Negeri Jakarta, amounting to 109 students. The instrument used was a questionnaire using a Likert scale. The results of the study show digital literacy competencies are influenced by several factors, including technical skills, critical understanding, and communicative abilities. Among these factors, the dominant factor affecting a person's digital literacy competence is a critical understanding factor. By having a critical understanding, they will have the ability to comprehensively analyze and evaluate media content. The results of this study can be a reference and input for all academics and education practitioners in identifying the digital literacy competencies of their students.
\end{abstract}

Keywords: Factor analysis, digital literacy competence Received: 04.12.2020 $\quad$ Accepted: 17.01.2021 $\quad$ Published: 03.02.2021

\section{INTRODUCTION}

The rapid flow of information today has an impact on social, cultural, economic, and educational structures. This development has the impact of the increasing openness and distribution of information and knowledge from and to all over the world across boundaries of distance, place, space, and time. In fact, human life in this digital era will always be related to technology. Technology has influenced and changed humans in everyday life, so that if we do not understand technology, it will be too late to master information, and will also be left behind to obtain various advanced opportunities (Johnston, 2020). The information has an important and real role, in the era of the information society or the scientific community. The advancement of information technology and the internet has resulted in very large digital information resources. Everyone is free to enter information in cyberspace without restrictions. The term digital native implies that the younger generation currently lives in the digital era, where the internet is part of their daily lives.

The very rapid development of information and communication technology has created an integration between one media and another which forms the emergence of new, more complex media. The new integrated media is internet-based digital media. The emergence of the internet resulted in the connection of information from all corners of any hemisphere running so fast that it made it easier for humans to obtain and disseminate information anywhere and anywhere, the ability of the internet was what led to the explosion of information. Indonesia has a small base of internet users today, but many connected citizens are tech-savvy. According to Mckinsey analysis based on data from "we are social 2016" shows that time spent on the internet via mobile devices as much 3.5 hours on average every day, as much time spent on social media 2.9 hours on average every day, facebook visitors as much as $90 \%$ internet user, and for online purchase $78 \%$ of population per active internet users (Das et al., 2016). Changes in the media structure in Indonesia, especially with the increasing use of cell phones, have changed the access and use of internet digital media among children and adolescents who tend to use personal computers to access the internet in internet cafes and school computer labs, laptops at home and above all cell phones or smartphone during daily activities.

Children and adolescents have three main motivations for accessing the internet, namely to seek information, to connect with old and new friends, and for entertainment. Information seeking is often driven by school assignments, while the use of social media and entertainment content is driven by personal needs 
(Meyers et al., 2013; Pangrazio, 2016). Meanwhile, the main recommendation generated from this study as input is that the internet has become an inseparable part of the daily lives of children and adolescents in Indonesia. This requires efforts to increase their awareness, knowledge, and skills in internet security. This can be achieved through socialization, literacy education, and training. The use and safety of digital media are very important, primarily from the perspective of children and adolescents before designing information programs on digital security, including understanding how they analyze and use digital technology, online communication, and risky or unsafe behavior (Pati \& Majhi, 2019; Treglia \& Tomassoni, 2019). The ability to process information obtained from digital sources can be said to be digital literacy. Digital literacy skills are very important for children and adolescents, especially students. Most students still use information that cannot be justified, such as not including a clear source of information for assignment references (Buckingham, 2008; Jan, 2018; West, 2019). Therefore, the ability to process information is very important for students. Essentially, students who have digital literacy, they can analyze and evaluate the information it gets digitally so that it can be accountable for the information. This literacy places a person as a more active consumer of information, for example being able to judge whether digital content is trusted or not

Digital literacy refers to an individual's ability to find, evaluate, and write clear information through writing and other media on various digital platforms (Bhatt, 2012; Fahrurrozi et al., 2019). Digital literacy is evaluated by individual grammar, composition, typing skills, and the ability to produce writing, images, audio, and design using technology. Digital literacy was initially focused on digital skills and stemming from the use of computers, the advent of the internet, and the use of social media, has caused the focus of digital literacy to shift to mobile devices (Chib et al., 2019; Marty et al., 2013; McDougall et al., 2018). Digital literacy does not replace traditional forms of literacy, instead of building on the skills that form the foundation in the form of functional literacy. Digital literacy that is built on the expansion of the role of social science research in the field of literacy is the concept of visual literacy, computer literacy, and information literacy (Julien, 2016; Martin \& Grudziecki, 2006). The term digital literacy was first put forward by Gilster \& Watson as the ability to understand and use information from various digital sources (Pool, 1997). He argues that digital literacy is the ability to use technology and information from digital devices effectively and efficiently in various contexts, such as academics, careers, and everyday life.

The use of digital media as a form of digital literacy is influenced by various information needs. The experience felt by users as a form of communication is an experience that must be continuously developed, so that the ability to understand digital literacy will increase. Coupled with the development of the internet which provides all kinds of information, both educational and entertainment information. Digital literacy is needed nowadays because it can neutralize fake news and can develop people's abilities in the era of digitalization. The use of digital literacy skills is supported by social media which can encourage changes in attitudes, behavior, and cognition for the better. The development of digital literacy skills has its own obstacles. Related to the constraints on the use of connectivity or the maximum utilization of media such as computers, devices, and internet connectivity which have a dependence on government regulations. These problems are related to usage. media.

Currently, measurements of what dimensions affect digital literacy skills are still relatively rare. This digital literacy competence is influenced by several factors including the ability to use, produce, analyze, and communicate messages through the media. The above abilities are one of the components of individual competencies, which is a person's ability to use and utilize media. Currently, measurements of what dimensions affect digital literacy skills are still relatively rare. This digital literacy competence is influenced by several factors including the ability to use, produce, analyze, and communicate messages through the media. The above abilities are one of the components of individual competencies, which are a person's ability to use and utilize media. Currently, measurements of what dimensions affect digital literacy skills are still relatively rare. This digital literacy competence is influenced by several factors including the ability to use, produce, analyze, and communicate messages through the media. The above abilities are one of the components of individual competencies, which is a person's ability to use and utilize media. Based on the description above, researchers are interested in conducting research related to factors that affect digital literacy competencies. This study aims to analyze the factors that influence and what dominant factors affect students' digital literacy competencies. 


\section{LITERATURE REVIEW}

\section{Digital Literacy Context}

The Internet enables long-distance communication between individuals across national and cultural boundaries. That is why media literacy is increasingly needed to form a society. Digital literacy is defined as the ability to understand and use information in various forms from a very wide variety of sources accessed through computer devices. Refers to Forgo's opinion, digital literacy is more associated with technical skills in accessing, compiling, understanding and disseminating information (Forgó, 2013). Digital literacy in everyday life can be demonstrated by the ability to process information through the media. The utilization of communication tools such as cellphones must be used wisely by users. Digital literacy is not only about the ability to use digital technology, but also the ability to place, organize, understand, evaluate, and analyze information using digital technology.

The basic principles of digital literacy development, among others, are as follows (1) understanding where a simple understanding includes the ability to extract ideas implicitly and explicitly from the media, (2) interdependence which means how a form of media relates to others in a potential, metaphorical way. , ideal, and literal and (3) social factors which mean who shares the information, to whom the information is given, and through what media the information is given can not only determine the long-term success of the media itself, but can also form an organic ecosystem to seek information, sharing information, storing information, and finally reshaping the media itself, and (4) curation talks about information storage, such as storing content on social media through the "save to read later" method is one type of literacy associated with the ability to understand the value of information and retain it so that it is more accessible and useful in the long term (Adam-Turner \& Burnett, 2018; Haluk Sivrikaya, 2020; Njenga, 2018).

In digital literacy skills are divided into several core competencies, among another internet searching, hypertextual navigation, content evaluation, knowledge assembly (Alexander et al., 2016; Kim, 2019). On the internet, searching competency means the ability to search for information on the internet and the ability to perform various activities on the internet. As for hypertextual navigation competence is knowledge of hypertext and hyperlinks and how they work, knowledge of the difference between reading textbooks and browsing via the internet, knowledge of how the web works, and the ability to understand the characteristics of web pages (Anisimova, 2020; Kaeophanuek et al., 2019). Content evaluation competence means the ability to distinguish between views and information content, the ability to analyze background information on the internet, the ability to evaluate a web address by understanding the various domains for each particular institution/country, the ability to analyze a web page, and knowing frequently asked questions in newsgroups (Pieterse et al., 2018). As for the knowledge assembly competency, it means the ability to search for information via the internet, the ability to create a personal newsfeed or the latest news notifications that will be obtained by joining and subscribing to the news in a newsgroup, the ability to crosscheck or double-check the information obtained, the ability to use all types of media to prove the truth of information. All these digital literacy competencies can be cultivated in students if they are always familiarized and trained on an ongoing basis.

This digital literacy competence can be supported by several factors. (Anisimova, 2020; Delacruz, 2018; Son \& Park, 2017) said that individual competence greatly affects digital literacy competence. Individual competencies are a person's ability to use and utilize media. Some of the abilities to use and utilize media include the ability to use, produce, analyze, and communicate messages through the media. Digital literacy development can be done in the realm of schools, families, and communities. With digital literacy, anyone is expected to have the ability to access, understand, and use digital media, communication tools, and networks. With this ability, they can create new information and disseminate it wisely. Besides being able to master the basics of computers, the internet, productive programs, as well as the security and confidentiality of an application, everyone is also expected to have a digital lifestyle so that all their daily activities are inseparable from the mindset and behavior of the digital society which is completely effective and efficient (Akbar \& Anggaraeni, 2017; Ata \& Ylldırım, 2019). Digital literacy learning must also involve understanding universal values that must be adhered to by every user, such as freedom of expression, privacy, cultural diversity, intellectual rights, copyright, and so on. Digital literacy allows a person to interact well and positively with their environment. Thus, digital literacy needs to be developed in families, schools, and communities as part of lifelong learning. Everyone is also expected to have a digital lifestyle so that all their daily activities are inseparable from the mindset and behavior of the digital society which is completely effective and efficient. Digital literacy learning must also involve understanding universal values that must be 
adhered to by every user, such as freedom of expression, privacy, cultural diversity, intellectual rights, copyright, and so on. Digital literacy allows a person to interact well and positively with their environment. Thus, digital literacy needs to be developed in families, schools, and communities as part of lifelong learning. Everyone is also expected to have a digital lifestyle so that all their daily activities are inseparable from the mindset and behavior of the digital society which is completely effective and efficient.

Digital literacy learning must also involve understanding universal values that must be adhered to by every user, such as freedom of expression, privacy, cultural diversity, intellectual rights, copyright, and so on. Digital literacy allows a person to interact well and positively with their environment. Thus, digital literacy needs to be developed in families, schools, and communities as part of lifelong learning. Digital literacy learning must also involve understanding universal values that must be adhered to by every user, such as freedom of expression, privacy, cultural diversity, intellectual rights, copyright, and so on. Digital literacy allows a person to interact well and positively with their environment. Thus, digital literacy needs to be developed in families, schools, and communities as part of lifelong learning. Digital literacy learning must also involve understanding universal values that must be adhered to by every user, such as freedom of expression, privacy, cultural diversity, intellectual rights, copyright, and so on. Digital literacy allows a person to interact well and positively with their environment. Thus, digital literacy needs to be developed in families, schools, and communities as part of lifelong learning.

\section{METHOD}

\section{Design Research}

This study aims to analyze the factors that influence a person's digital literacy competence and which factors predominantly influence it. The type of research method used is a method. The method used is the descriptive method. This is used to get an overview of the problem that is the focus of the author's research. The focus of this research is on the dominant factors that affect digital literacy competencies. Research using a quantitative approach where the research data is in the form of numbers and statistical data analysis. The numbers generated from the data collected in the field are used as a percentage.

\section{Respondent}

The sampling technique that the researchers chose was probability sampling with a simple random sampling technique. The research sample is relatively homogeneous following the research objectives. The research sample was determined using the Slovin formula, with a total of 109 students in the primary school teacher education study program Universitas Negeri Jakarta.

\section{Research Instruments}

The research instrument used in this study included a questionnaire. The questionnaire used in this study used a Likert scale. Through this Likert scale, respondents are asked to respond by choosing one of the alternatives from the five available answers. The answers of each variable are given a score of one to five with the details, namely Strongly Agree (SS) with a score of 5, Agree (S) with a score of 4, Disagree with a score of 3, Disagree (TS) with a score of 2 and Strongly Disagree (STS). ) with a score of 1.

\section{Data Analysis Technique}

Data analysis using factor analysis is data analysis used to determine the dominant factors in explaining a problem. The purpose of factor analysis is to find the main factors affecting the dependent variable from a series of tests conducted on a series of independent variables as factors. Data processing in this study used statistical factor analysis with factor analysis using SPSS 17.0 software. Factor analysis is used to find the dominant factors that affect digital literacy competencies. The results of processing will display the KMO and Bartlett Test tables, where these results show the correlation between variables that affect learning outcomes with the desired value> 0.5 and the significance of the study is 0.05 . The correlation between independent variables can be seen in the anti-image matrices table. The value of the factors that affect the learning outcomes in detail is obtained from the commonalities table data in the extraction column. 


\section{RESULTS}

The research data obtained what factors affect students' digital literacy competencies. The results of the research data are described below:

Table 1. Analysis of Factors Affecting Digital Literacy Competence KMO and Bartlett's Test

\begin{tabular}{|l|l|l|}
\hline \multicolumn{2}{|l|}{ Kaiser-Meyer-Olkin Measure of Sampling Adequacy } & .650 \\
\hline Bartlett's Test of Sphericity & Approx. Chi-Square & 165,839 \\
\hline & Df & 15 \\
\hline & Sig. & .000 \\
\hline
\end{tabular}

Table 2. Independent Intervariable Correlation

\begin{tabular}{|l|l|l|l|l|}
\hline & & Technical Skill & $\begin{array}{l}\text { Critical } \\
\text { Understanding }\end{array}$ & $\begin{array}{l}\text { Communicaticative } \\
\text { Ability }\end{array}$ \\
\hline $\begin{array}{l}\text { Anti-image } \\
\text { Correlation }\end{array}$ & Technical Skill & $.719 \mathrm{a}$ & .084 & -204 \\
\hline & $\begin{array}{l}\text { Critical } \\
\text { Understanding }\end{array}$ & -.477 & $.648 \mathrm{a}$ & -.503 \\
\hline & $\begin{array}{l}\text { Communicaticative } \\
\text { Ability }\end{array}$ & -.0 .27$. & -358 & $.805 \mathrm{a}$ \\
\hline
\end{tabular}

a. Measures of Sampling Adequacy (MSA)

Table 3. Factors Affecting Digital Literacy Competence Communalities

\begin{tabular}{|l|l|l|}
\hline & Initial & Extraction \\
\hline Technical Skill & 1,000 & .615 \\
\hline Critical Understanding & 1,000 & .806 \\
\hline Communicaticative Ability & 1,000 & .668 \\
\hline
\end{tabular}

Extraction Method: Principal Component Analysis

\section{DISCUSSION}

The magnitude of the KMO and Bartlett Test values (Table 1) for the correlation between the variables affect digital literacy where the desired value is $>0.5$ and the research significance is 0.05 . Based on the calculation results, the KMO value is 0.650 , which means it is greater than 0.5. Meanwhile, the significance of Bartlett's test of sphericity is 0,000 . It can be said that the variables and samples used to allow further research to be carried out. The correlation between the independent variables can be seen in the Anti-Image Matrices table. The value to be considered is the MSA (Measure of Sampling Adequacy) which ranges from 0 to 1, with the following conditions are

1. $M S A=1$, the variable can be predicted without error by other variables.

2. $M S A>0.5$, the variable can still be predicted and can be analyzed further.

3. MSA $<0.5$, the variable cannot be predicted and cannot be further analyzed, or excluded from other variables.

The magnitude of the correlation between the independent variables in table 2 shows the MSA value which is marked with the letter a. The MSA results for the correlation between independent variables are technical skill is 0.719 , critical understanding is 0.648 , and communicative ability is 0.805 . Based on all the MSA results, all independent variables are greater than 0.5 . This means that all independent variables can be analyzed further.

The value of the factor table 3 affects digital literacy. The value of the factors that affect students' digital literacy competencies is shown from the extraction value. Factor value technical skill affects student digital literacy by 0.615 or $61.5 \%$, critical understanding by 0.806 or $80.6 \%$, and communicative Abilityby 0.668 or $66.8 \%$. Based on these results, the dominant factors affecting digital literacy competence are critical understanding.

In essence, people who have a critical understanding of digital information can conduct comprehensive analysis and evaluation of media content. Besides, someone with a good critical understanding, of course, will have an understanding of media content and its functioning, knowledge about 
media and media regulation, and user behavior in using internet media. The criterion for critical understanding includes informants' trust in the mass media or the internet; ability to discern the truth of news site content; ability to understand government regulations related to media; and check news sources (Çam \& Kiyici, 2017; Tecce DeCarlo et al., 2018). Thus this critical understanding factor becomes one of the dominant factors in influencing one's digital literacy competence.

As with other factors such as technical skills, which are the ability to access and operate the media. When someone has technical skills then they have mastered computer and internet skills, balances, and active use of media, and advanced internet use. As for individuals who have communicative abilities, they can socialize and participate through the media and produce media content. This is because communicative abilities include several dimensions, namely social relations, citizen participation, and content creation (Chan et al., 2017; Haluk Sivrikaya, 2020; Kiersten, 2018). Thus individual digital literacy competencies are influenced by several factors, including technical skills, critical understanding, and communicative abilities. Among these factors, the dominant factor affecting a person's digital literacy competence is a critical understanding factor.

\section{CONCLUSION}

Based on the research results, the dominant factors affecting digital literacy competence are critical understanding. By having a critical understanding, they will have the ability to comprehensively analyze and evaluate media content. Following the research (Phuapan et al., 2016; Traxler, 2018; Yildiz, 2020) shows that a digitally literate person must be critical of information obtained from digital sources. This must be owned so that they can distinguish sites that contain good and bad things, understand government regulations, can cross-check news sources, and can maintain their privacy. The results of this study can be a reference and input for all academics and education practitioners in identifying the digital literacy competencies of their students.

\section{REFERENCES}

Adam-Turner, N., \& Burnett, D. (2018). Leadership Perspectives of Digital Learning and Digital Literacy Adoption at Rural Community Colleges. Community College Enterprise, 24(2), 21.

Akbar, M. F., \& Anggaraeni, F. D. (2017). Technology in Education: Digital Literation and Self-Directed Learning in Students Students. Jurnal Indigenous, 2(1), 28-38.

Alexander, B., Adams Becker, S., \& Cummins, M. (2016). An NMC Horizon Project Strategic Brief. 3(October). http://cdn.nmc.org/media/2016-nmc-horizon-strategic-brief-digital-literacy.pdf

Anisimova, E. S. (2020). Digital literacy of future preschool teachers. Journal of Social Studies Education Research, 11(1), 230-253.

Ata, R., \& Yıldırım, K. (2019). Exploring turkish pre-service teachers' perceptions and views of digital literacy. Education Sciences, 9(1). https://doi.org/10.3390/educsci9010040

Bhatt, I. (2012). Digital literacy practices and their layered multiplicity. Educational Media International, 49(4), 289-301. https://doi.org/10.1080/09523987.2012.741199

Buckingham, D. (2008). Defining Digital Literacy: What Do Young People Need to Know. Digital Literacies: Concepts, Policies and Practices, 73-89.

Çam, E., \& Kiyici, M. (2017). Perceptions of Prospective Teachers on Digital Literacy. Malaysia Online Journal of Educational Techology, 5(4), 29-44.

Chan, B. S. K., Churchill, D., \& Chiu, T. K. F. (2017). Digital Literacy Learning In Higher Education Through Digital Storytelling Approach. Journal of International Education Research (JIER), 13(1), 1. https://doi.org/10.19030/jier.v13i1.9907

Chib, A., Bentley, C., \& Wardoyo, R. J. (2019). Distributed digital contexts and learning: Personal empowerment and social transformation in marginalized populations. Comunicar, 27(58), 51-60. https://doi.org/10.3916/C58-2019-05

Das, K., Gryseels, M., Sudhir, P., \& Tan, K. T. (2016). Unlocking Indonesia's Digital Opportunity. McKinsey \& Company, October, $1-28$. https://www.mckinsey.com/ /media/McKinsey/Locations/Asia/Indonesia/Our Insights/Unlocking Indonesias digital opportunity/Unlocking_Indonesias_digital_opportunity.ashx

Delacruz, S. (2018). Building Digital Literacy Bridges: Connecting Cultures and Promoting Global Citizenship 
in Elementary Classrooms through School-Based Virtual Field Trips. TechTrends. https://doi.org/10.1007/s11528-018-0350-1

Fahrurrozi, Hasanah, U., \& Dewi, R. S. (2019). Integrated Learning Design Based on Google Classroom to Improve Student Digital Literacy. 2019 5th International Conference on Education and Technology, ICET 2019, 108-111. https://doi.org/10.1109/ICET48172.2019.8987219

Forgó, S. (2013). New Media, New Media literacy, new methods in education. Proceedings of the 2013 IEEE 63rd Annual Conference International Council for Education Media, ICEM 2013. https://doi.org/10.1109/CICEM.2013.6820148

Haluk Sivrikaya, M. (2020). An Analysis on Digital Literacy Level of Faculty of Sports Science Students. Asian $\begin{array}{llll}\text { Journal of } \text { Education } & \text { Training, 6(2), }\end{array}$ https://doi.org/10.20448/journal.522.2020.62.117.121

Jan, S. (2018). Investigating the relationship between students' digital literacy and their attitude towards using ICT. 2017.

Johnston, N. (2020). The Shift towards Digital Literacy in Australian University Libraries: Developing a Digital Literacy Framework. Journal of the Australian Library and Information Association, 69(1), 93-101. https://doi.org/10.1080/24750158.2020.1712638

Julien, H. (2016). Beyond the hyperbole: Information literacy reconsidered. Communications in Information Literacy, 10(2), 124-131. https://doi.org/10.15760/comminfolit.2016.10.2.28

Kaeophanuek, S., Na-Songkhla, J., \& Nilsook, P. (2019). A learning process model to enhance digital literacy using critical inquiry through digital storytelling (CIDST). International Journal of Emerging Technologies in Learning, 14(3), 22-37. https://doi.org/10.3991/ijet.v14i03.8326

Kiersten, G. (2018). Transferable Digital Literacy Knowledge.

Kim, K. T. (2019). The structural relationship among digital literacy, learning strategies, and core competencies among south korean college students. Educational Sciences: Theory and Practice, 19(2), 3-21. https://doi.org/10.12738/estp.2019.2.001

Martin, A., \& Grudziecki, J. (2006). DigEuLit: Concepts and Tools for Digital Literacy Development. Innovation in Teaching and Learning in Information and Computer Sciences, 5(4), 249-267. https://doi.org/10.11120/ital.2006.05040249

Marty, P. F., Alemanne, N. D., Mendenhall, A., Maurya, M., Southerland, S. A., Sampson, V., Douglas, I., Kazmer, M. M., Clark, A., \& Schellinger, J. (2013). Scientific inquiry, digital literacy, and mobile computing in informal learning environments. Learning, Media and Technology, 38(4), 407-428. https://doi.org/10.1080/17439884.2013.783596

McDougall, J., Readman, M., \& Wilkinson, P. (2018). The uses of (digital) literacy. Learning, Media and Technology, 43(3), 263-279. https://doi.org/10.1080/17439884.2018.1462206

Meyers, E. M., Erickson, I., \& Small, R. V. (2013). Digital literacy and informal learning environments: An $\begin{array}{llll}\text { introduction. } \quad \text { Learning, } & \text { Media }\end{array}$ https://doi.org/10.1080/17439884.2013.783597

Njenga, J. K. (2018). Digital literacy: The quest of an inclusive definition. Reading \& Writing, 9(1), 1-7. https://doi.org/10.4102/rw.v9i1.183

Pangrazio, L. (2016). Reconceptualising critical digital literacy. Discourse, 37(2), 163-174. https://doi.org/10.1080/01596306.2014.942836

Pati, B., \& Majhi, S. (2019). Information Literacy Skill. International Journal of Digital Literacy and Digital Competence, 10(1), 15-33. https://doi.org/10.4018/ijdldc.2019010102

Phuapan, P., Viriyavejakul, C., \& Pimdee, P. (2016). An Analysis of Digital Literacy Skills among Thi University Seniors. IJet, 16(03).

Pieterse, E., Greenberg, R., \& Santo, Z. (2018). A multicultural approach to digital information literacy skills evaluation in an Israeli college. Communications in Information Literacy, 12(2), 107-127. https://doi.org/10.15760/comminfolit.2018.12.2.4

Pool, C. R. (1997). A New Digital Literacy A Conversation with Paul Gilster. Educational Leadership, 55(3), 611. http://namodemello.com.br/pdf/tendencias/tecnolnocurric.pdf

Son, J.-B., \& Park, M. (2017). Digital literacy of language learners in two different contexts sang-soon Park. 13(2), 1832-4215.

Tecce DeCarlo, M. J., Grant, A., Lee, V. J., \& Neuman, D. (2018). Information and Digital Literacies in a Kindergarten Classroom: An I-LEARN Case Study. Early Childhood Education Journal, 46(3), 265-275. https://doi.org/10.1007/s10643-017-0857-7 
Traxler, J. (2018). Digital literacy: A palestinian refugee perspective. Research in Learning Technology, 26(1063519), 1-21. https://doi.org/10.25304/rlt.v26.1983

Treglia, E., \& Tomassoni, R. (2019). The Development of Digital Competences and Emotional Skills Through the Use of Audio-Visual Technologies. International Journal of Digital Literacy and Digital Competence, 10(1), 55-60. https://doi.org/10.4018/ijdldc.2019010105

West, J. A. (2019). Using new literacies theory as a lens for analyzing technology-mediated literacy classrooms. E-Learning and Digital Media, 16(2), 151-173. https://doi.org/10.1177/2042753019828355

Yildiz, E. P. (2020). Opinions of academicians on digital literacy: A phenomenology study. Cypriot Journal of Educational Sciences, 15(3), 469-478. https://doi.org/10.18844/cjes.v15i3.4913 